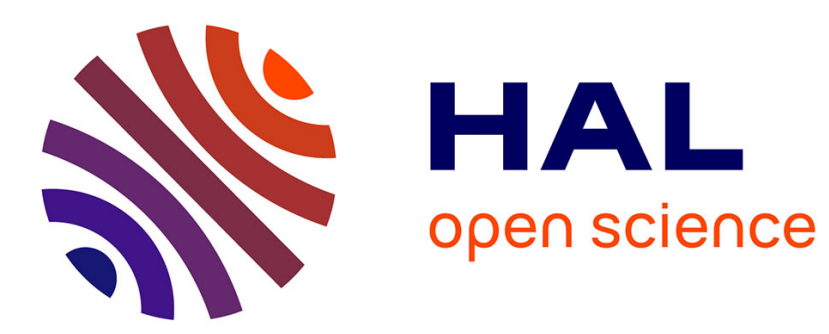

\title{
Disposition of everolimus in mdr1a-/1b- mice and after a pre-treatment of lapatinib in Swiss mice
}

C. Chu, C. Abbara, M.S. Noël-Hudson, L. Thomas-Bourgneuf, P. Gonin, R. Farinotti, L. Bonhomme-Faivre

\section{> To cite this version:}

C. Chu, C. Abbara, M.S. Noël-Hudson, L. Thomas-Bourgneuf, P. Gonin, et al.. Disposition of everolimus in mdr1a-/1b- mice and after a pre-treatment of lapatinib in Swiss mice. Biochemical Pharmacology, 2009, 77 (10), pp.1629. 10.1016/j.bcp.2009.02.013 . hal-00493494

\section{HAL Id: hal-00493494 https://hal.science/hal-00493494}

Submitted on 19 Jun 2010

HAL is a multi-disciplinary open access archive for the deposit and dissemination of scientific research documents, whether they are published or not. The documents may come from teaching and research institutions in France or abroad, or from public or private research centers.
L'archive ouverte pluridisciplinaire $\mathbf{H A L}$, est destinée au dépôt et à la diffusion de documents scientifiques de niveau recherche, publiés ou non, émanant des établissements d'enseignement et de recherche français ou étrangers, des laboratoires publics ou privés. 


\section{Accepted Manuscript}

Title: Disposition of everolimus in mdr1a-/1b- mice and after a pre-treatment of lapatinib in Swiss mice

Authors: C. Chu, C. Abbara, M.S. Noël-Hudson, L.

Thomas-Bourgneuf, P. Gonin, R. Farinotti, L.

Bonhomme-Faivre

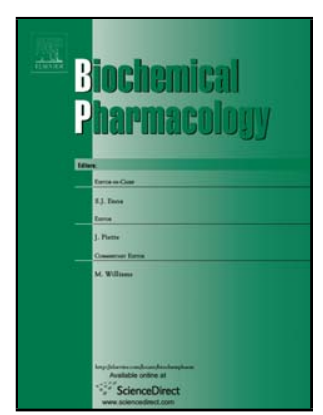

PII:

S0006-2952(09)00114-2

DOI: doi:10.1016/j.bcp.2009.02.013

Reference: BCP 10093

To appear in: $\quad B C P$

Received date: $\quad 23-12-2008$

Revised date: $\quad 18-2-2009$

Accepted date: $\quad$ 18-2-2009

Please cite this article as: Chu C, Abbara C, Noël-Hudson MS, Thomas-Bourgneuf L, Gonin P, Farinotti R, Bonhomme-Faivre L, Disposition of everolimus in mdrla-/1bmice and after a pre-treatment of lapatinib in Swiss mice, Biochemical Pharmacology (2008), doi:10.1016/j.bcp.2009.02.013

This is a PDF file of an unedited manuscript that has been accepted for publication. As a service to our customers we are providing this early version of the manuscript. The manuscript will undergo copyediting, typesetting, and review of the resulting proof before it is published in its final form. Please note that during the production process errors may be discovered which could affect the content, and all legal disclaimers that apply to the journal pertain. 
Lapatinib increases 2.5-fold everolimus AUC in mice. A 38.5\% decrease of P-gp expression was

observed in duodenum with a lapatinib pre-treatment. An inhibition of CYP 450 could not be excluded.
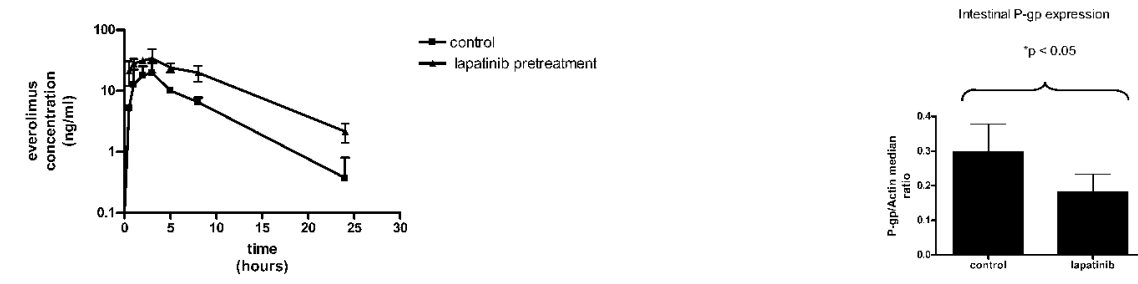
Disposition of everolimus in mdr1a-/1b- mice and after a pre-treatment of lapatinib in

\section{Swiss mice.}

Chu $\mathrm{C}^{1}$, Abbara $\mathrm{C}^{1}$, Noël-Hudson $\mathrm{MS}^{2}$, Thomas-Bourgneuf $\mathrm{L}^{1}$, Gonin $\mathrm{P}^{3}$, Farinotti $\mathrm{R}^{2}$, Bonhomme-Faivre $\mathrm{L}^{1,2}$

${ }^{1}$ Laboratory of Pharmacology, Hôpital Paul Brousse, Villejuif France,

${ }^{2}$ UPRES EA 2706 Faculty of Pharmaceutical Sciences, Université Paris Sud XI, Châtenay Malabry, France,

${ }^{3}$ Animals Department, Institut Gustave Roussy, Villejuif France.

Corresponding Author:

Céline Chu

Hôpital Paul Brousse

14 avenue Paul Vaillant Couturier 94800 Villejuif

Phone number: +33-1-45-59-38-38; Fax number: +33-1-45-59-37-16

Email address: celinechu82@yahoo.fr 


\section{$\underline{\text { ABSTRACT }}$}

The aim of this study was to document in vivo the transport of everolimus (inhibitor of mTOR) by P-glycoprotein (P-gp), and to investigate the influence of lapatinib (inhibitor of Pgp) on everolimus disposition.

Pharmacokinetics of everolimus $(0.25 \mathrm{mg} / \mathrm{kg})$ has been investigated after oral administration in mdrla-/1b- mice compared to the wild type. Also, everolimus pharmacokinetics was characterized after oral administration on Swiss mice either alone or after 2 days of pretreatment of lapatinib $(200 \mathrm{mg} / \mathrm{kg})$. The influence of lapatinib pre-treatment on intestinal P-gp expression was investigated by Western blot analysis. The noncompartmental analysis was performed using Winonlin ${ }^{\circledR}$ professional version 4.1 software (Pharsight, Mountain View, CA). The areas under the plasma concentration-time curve (AUC) were compared using Bailer's method.

A significant 1.3-fold increase of everolimus AUC observed in mdrla-/1b- mice suggested that everolimus is transported in vivo by intestinal P-gp in mice. In addition, a 2.6-fold significant increase of everolimus AUC with lapatinib pre-treatment as compared with the everolimus alone group was noticed. The elimination half-life were comparable $\left(\mathrm{t}_{1 / 2}=5.3 \mathrm{~h}\right.$ vs. $\mathrm{t}_{1 / 2}=4 \mathrm{~h}$ ). A $38.5 \%$ significant decrease of P-gp expression was observed in duodenum segment in lapatinib pre-treated group as compared with control group.

In conclusion, lapatinib enhanced everolimus absorption by decreasing intestinal P-gp expression. An inhibition of CYP 450 could not be excluded. These results confirm the necessity of a therapeutic monitoring of everolimus combined with an inhibitor of the P-gp and CYP P450 like lapatinib in a future anti-tumor treatment.

Key words: lapatinib; everolimus; P-glycoprotein; pharmacokinetics; mice Category of article: Pharmacokinetics and Drug Metabolism 


\section{1- INTRODUCTION}

Everolimus (Certican $\left.{ }^{\circledR}\right), 40-\mathrm{O}-(2$-hydroxyethyl) - rapamycine, is a new immunosuppressant used in cardiac and renal transplantation [1,2] This drug belongs to the family of inhibitors of the mTOR protein (mammalian target of rapamycin) which is a regulatory protein of cells metabolism, growth and proliferation. Since mTOR protein is present both in hematopoietic cells (T cells or B) and in non hematopoietic cells (such as smooth muscle cell), everolimus will inhibits growth factors stimulated proliferation. Several studies showed the interest of everolimus as an anti-tumor agent. An increase of survival is observed in patients in post liver transplantation neoplasms who received everolimus as compared to patients who received only an inhibitor of calcineurine (ciclosporin or tacrolimus) with steroids at 6,12 , and 24 months $(100 \%, 90 \%, 72 \%$ vs. $50 \%, 29 \%, 14 \%)$ [3]. Everolimus anti-tumor properties could also be explained by the presence of the protein $\mathrm{mTOR}$ in many tumors, an inhibition of tumor growth and angiogenesis was observed in treated human tumor cells in ovarian cancer resistant cisplatine [4].

Everolimus is highly metabolized in intestine and liver. Everolimus absolute oral bioavaibility in rats is about $16 \%$ [5]. Everolimus is substrate of P-glycoprotein (P-gp) and also of P450 3A4, 3A5 and 2C8 cytochromes [6-8]. Cytochromes P450 3A (CYP3A) and P-glycoprotein (P-gp) are located in enterocytes and hepatocytes. The CYP3A/P-gp system contributes to the first-pass metabolism of many drugs, resulting in a limited bioavailability [9]. Cytochrome P450 isoenzymes are parts of the phase I metabolizing enzymes. The CYP3A subfamily is predominant and is involved in the metabolism of more than $70 \%$ of currently administered drugs. The CYP $3 \mathrm{~A}$ represent almost $30 \%$ of the cytochromes in the liver and $70 \%$ of the cytochromes in the small intestine [10]. Many studies have demonstrated that inhibitors of cytochromes $3 \mathrm{~A}$ are leading to an increase of AUC of drug substrates with a prolongation of half time elimination [11,12]. P-gp is part of a large family of efflux transporters which is 
expressed in the gonads, kidneys, biliary system, intestinal epithelium, brain capillaries and lymphocytes. P-gp is coded by the multidrug resistance MDR1 genes in humans and the mdrla and mdrlb in mice and rats. These genes encode drug-transporting protein that can cause multidrug resistance in tumor cells by decreasing intracellular drug levels. Enhanced expression of P-gp is considered to be a major mechanism of chemotherapeutics resistance [13]. Conversely, inhibitors of P-gp may increase the oral absorption of drugs transported by P-gp. For example, verapamil enhanced bioavaibility of etoposide in rats [14]. In vitro study using human intestinal cell line (Caco-2) has shown that everolimus is a potent substrate for P-gp-like mediated efflux and this efflux was completely inhibited by verapamil. [15]. Modifications of pharmacokinetics of drugs substrates of cytochromes or P-gp by many inhibitors of these proteins are leading to therapeutic drug monitoring. As everolimus is substrate of cytochromes and P-gp, it is conceivable that pharmacokinetics parameters of this drug could be modified after a pre-treatment by P-gp inhibitor.

Lapatinib is an inhibitor of tyrosine kinase receptors (HER 1 and HER 2) which is indicated in combination with capecitabine for the treatment of patients with advanced or metastatic breast cancer whose tumors overexpress HER2 [16,17]. Lapatinib was chosen in this pharmacological study for several reasons. First, in vitro and in vivo studies showed that lapatinib decreases the expression of P-gp and inhibits cytochrome 3A4 and BCRP [18-20]. Thus, everolimus pharmacokinetic parameters could be modified after a lapatinib pretreatment. Second, it is relevant to study the pharmacological interaction of these two drugs acting by two different anti-tumor mechanisms (inhibition of mTor protein and inhibition of tyrosine kinases receptor) as they could be combined for an anti-tumor treatment. As the matter of fact, a Phase I Study evaluates the combination of lapatinib and everolimus in patients with advanced solid tumors or non-Hodgkin's lymphoma [21].

The present pharmacological study was to thus undertaken with a double purpose: a) to 
document in vivo the effect of intestinal P-gp on everolimus disposition, b) to investigate the effect of lapatinib pre-treatement on everolimus pharmacokinetics and its influence on intestinal P-gp expression. Therefore, we have investigated the pharmacokinetics of everolimus and digoxin (substrate test of P-gp) after oral administration in mice with naturally deficient in P-gp (mdr 1a-/1b-) compared to the wild type (Fvb mice). In a second time, everolimus pharmacokinetic parameters were determined after oral administration either alone or after lapatinib pretreatment in Swiss mice. 


\section{2- MATERIALS AND METHODS}

\section{2-1. Drugs}

Digoxin, (digoxine nativelle ${ }^{\circledR}$ ) was purchased from Procter Gamble Pharmaceuticals (Asnières-sur-Seine, France). $100 \mu \mathrm{L}$ of suspension $(50 \mu \mathrm{g} / \mathrm{mL})$ was diluted in $900 \mu \mathrm{L}$ of sterile water to obtain a stock solution at $5 \mu \mathrm{g} / \mathrm{mL}$. Everolimus, $\left(\right.$ Certican $\left.^{\circledR}\right)$ was purchased from Novartis Pharma SAS (Rueil-Malmaison, France). The oral preparation was obtained by dispersion of a tablet $(0.25 \mathrm{mg})$ in $10 \mathrm{~mL}$ of sterile water $(0.025 \mathrm{mg} / \mathrm{mL})$. Lapatinib, (Tyverb $^{\circledR}$ ) was purchased from GlaxoSmith Kline (Marly-le-Roi, France). The oral preparation was obtained by dispersion of a tablet $(250 \mathrm{mg})$ in $25 \mathrm{~mL}$ of sterile water (10 $\mathrm{mg} / \mathrm{mL})$.

\section{2-2. Animals}

Two strains of mice were used in this study. The first strain of mice was Fvb (sensitive to the B strain of friend leukemia) mice. The Fvb mice were used in digoxin and everolimus pharmacocinetics studies to document the effect of P-gp on everolimus disposition. For each drug, the wild type was compared to mdrla-/1b- mice (mice naturally deficient of P-gp). The second strain was Swiss mice OF1. OF1 mice were used to study the influence of lapatinib pretreatment on everolimus disposition.

All mice used in the study were female mice (20-30 g) and provided by Charles River Laboratories (Orléans, France). They were caged under standard laboratory conditions, with tap water and regular chow provided ad libitum in a 12 hours/12 hours light/dark cycle at a temperature of $21-23^{\circ} \mathrm{C}$. Anesthesia was induced with $5 \%$ isoflurane and maintained with $2.5 \%$ isoflurane in air. The animals were treated in accordance with the European committee standards concerning the care and use of laboratory animals. 


\section{2-3. Digoxin Pharmacokinetic Study}

Fvb and mdr1a-/b- mice in each group orally received $0.03 \mathrm{mg} / \mathrm{kg}$ of digoxin. They were anesthetized with isoflurane and the blood samples were collected by cardiac puncture at 15 , 30 min and 1, 2, 3, 4, 6, 8 and $24 \mathrm{hr}$ after the administration of digoxin on heparinazed tubes. The samples were centrifuged at $12.000 \mathrm{~g}$ for $8 \mathrm{~min}$ and the plasma was harvested into clean tubes. For digoxin quantification, an automated method was used. Plasma digoxin concentrations were measured with Fluorescent Polarization Assay (FPIA) on TDx ${ }^{\circledR}$ using Digoxin II ${ }^{\circledR}$ reagent kit (Abbott Diagnostic, Rungis, France). This method was linear up to 5 $\mathrm{ng} / \mathrm{mL}$ with a limit of quantification at $0.2 \mathrm{ng} / \mathrm{mL}$. All plasma samples were assayed together with calibration standard and quality control.

\section{2-4. Everolimus Pharmacokinetic Study}

Fvb and mdrla- $/ \mathrm{b}$ - mice in each group orally received $0.25 \mathrm{mg} / \mathrm{kg}$ of everolimus. The mice were anesthetized with isoflurane and the blood samples were collected by cardiac puncture at 30 min and 1, 2, 3, 5, 8 and $24 \mathrm{hr}$ after the administration of everolimus on EDTA tubes. For everolimus quantification, an automated method was used. Blood everolimus concentrations were measured with Fluorescent Polarization Assay (FPIA) on $\mathrm{TDx}^{\circledR}$ using INNOFLUOR ${ }^{\circledR}$ CERTICAN ${ }^{\circledR}$ kit (Biomedical diagnostics, Marne la Vallée, France). This method was linear up to $40 \mathrm{ng} / \mathrm{mL}$ with a limit of quantification at $2 \mathrm{ng} / \mathrm{mL}$. All blood samples were assayed together with calibration standard and quality control.

\section{2-5. Everolimus Pharmacokinetic After Lapatinib Pre-Treatment}

Swiss mice were divided into two groups. The first one orally received $0.25 \mathrm{mg} / \mathrm{kg}$ of everolimus, the second one orally received $100 \mathrm{mg} / \mathrm{kg}$ of lapatinib twice a day for two days and $0.25 \mathrm{mg} / \mathrm{kg}$ of everolimus on the third day. The collection of everolimus blood samples 
and the quantification of everolimus blood concentration were done in the same conditions described for everolimus pharmacokinetic studies in Fvb and mdr1a-/1b- mice.

\section{2-6. Data Analysis. Pharmacokinetic studies}

As each animal provided only one sample of blood, data from animals of the same group were pooled using a naïve averaging data approach [22]. The noncompartmental analysis was performed using Winonlin ${ }^{\circledR}$ professional version 4.1 software (Pharsight, Mountain View, $\mathrm{CA})$. Data were used to estimate the mean maximal concentration $\left(\mathrm{C}_{\max }\right)$ and the time necessary to reach maximal concentration $\left(\mathrm{T}_{\max }\right)$. In addition, for each treatment, the elimination rate constant $\left(\mathrm{k}_{\mathrm{e}}\right)$ and the area under the mean concentration-time curve $\left(\mathrm{AUC}_{0 \rightarrow \text { Tlast }}\right)$ were estimated. The elimination rate constant $\left(\mathrm{k}_{\mathrm{e}}\right)$ was estimated as the slope of the log-linear terminal portion of the plasma concentration vs. time curve, determined using unweighted linear least-squares regression analysis.

Additionally, from the estimated parameters, the terminal elimination half-life $\left(t_{1 / 2}\right)$ for each group was derived and calculated as $\mathrm{t}_{1 / 2}=\ln 2 / \mathrm{k}_{\mathrm{e}}$.

\section{2-7. Semiquantitative Determination of P-gp Expression by Western Blot Analysis}

P-gp expression was measured in three segments of intestine (duodenum, jejunum, and ileum) by Western Blot analysis in two groups of mice: (1) 3 female Swiss mice non-pretreated, (2) 3 female Swiss mice with a lapatinib pre-treatment. For last group, mice orally received 100 $\mathrm{mg} / \mathrm{kg}$ of lapatinib twice a day for 2 days and $100 \mathrm{mg} / \mathrm{kg}$ of lapatinib on the third day. The intestines were removed 6 hours after the last administration of lapatinib on the third day. Tissues were cut into small pieces and suspended in three volumes of $0.25 \mathrm{M}$ sucrose, $50 \mathrm{mM}$ phosphate buffer, $\mathrm{pH}$ 7.20, $1 \mathrm{mM}$ EGTA, $2 \mathrm{mM} \mathrm{MgCl}_{2}$, and protease inhibitors: $5 \mu \mathrm{g} / \mathrm{ml}$ leupeptin, $0.15 \mathrm{mg} / \mathrm{ml}$ benzamidine, $5 \mu \mathrm{g} / \mathrm{ml}$ aprotinin, $1 \mu \mathrm{g} / \mathrm{ml}$ pepstatin, and $16 \mathrm{mg} / \mathrm{ml}$ 
phenylmethylsulfonyl fluoride (PMSF) (Sigma-Aldrich, St. Louis, MO, USA). The suspension was then homogenized in a glass tube. The homogenate was centrifuged at $500 \mathrm{~g}$ for $15 \mathrm{~min}$. The supernatant obtained was then centrifuged at 3,000 $\mathrm{g}$ for $15 \mathrm{~min}$. The pellet was washed twice with three volumes of $0.25 \mathrm{M}$ sucrose, $50 \mathrm{mM}$ phosphate buffer, $\mathrm{pH} 7.20,2$ $\mathrm{mM} \mathrm{MgCl}_{2}$, and protease inhibitors and centrifuged at 3,000 $\mathrm{g}$ for $15 \mathrm{~min}$. Protein concentrations were determined using the colorimetric bicinchoninic assay kit (SigmaAldrich, St. Louis, MO, USA), with bovine serum albumin (BSA;Sigma-Aldrich) as a standard. Proteins $(40 \mu \mathrm{g})$ were separated by SDS-polyacrylamide gel electrophoresis on an $8 \%$ polyacrylamide gel and transferred onto a nitrocellulose membrane (Amersham, Orsay, France). The nitrocellulose membranes were then incubated with a primary antibody (C219, diluted to 1:100; DakoCytomation Denmark A/S, Glostrup, Denmark), washed, and finally incubated with a peroxidase-conjugated anti-mousse $\operatorname{IgG}$ secondary antibody. The immunoreactive bands were visualized by the enhanced Chemi-luminescent system (Perkin Elmer life science, Boston, USA). The nitrocellulose membranes were also incubated with anti- $\beta$ actin (dilted to 1:5000; Sigma-Aldrich, St. Louis, USA) to normalize P-gp expression. The autoadiographs of P-gp and $\beta$ actin proteins were scanned by densitometry using the image $\mathbf{J}$ software to obtain a quantitative evaluation of protein levels in the three segments of intestines.

\section{2-8. Statistical Analysis}

Pharmacokinetic Studies: The mean $\mathrm{AUC}_{0 \rightarrow \text { Tlast }}$ estimated for each study group after administration of treatment were compared using Bailer's method [23].

The test for the equality of the mean AUC between each study group after administration of treatment was performed using the standard Wald statistic. Under the null hypothesis that 
mean AUCs are equal, this statistic follows a normal distribution. The null hypothesis was rejected if $\left|Z_{\mathrm{obs}}\right|$ was greater than 1.96 .

Western Blot Studies: In the Western blot analysis of the P-gp expression, the intensity $P-g p / \beta$ actin ratio was compared using Wilcoxon's test with a significant level fixed at 0.05 .

\section{3- RESULTS}

\section{3-1. Digoxin Pharmacokinetic Study}

The results of the non-compartimental analysis in Fvb mice group and in mdr1a-/1b- mice group after the administration of digoxin are summarized in Table 1.

As shown in Fig. 1, the oral administration of digoxin to the mdr1a-/1b- mice group resulted in a mean $\mathrm{C}_{\max } 3$ fold higher than the mean $\mathrm{C}_{\max }$ in the Fvb group. Also, $\mathrm{AUC}_{0 \rightarrow \text { Tlast }}$ of the mdrla-/1b- group is 5.9 fold greater than $\mathrm{AUC}_{0 \rightarrow \text { Tlast }}$ of the Fvb group $(p<0.00001$, Bailer's method). The half-life of elimination were comparable (5.7 vs. $5.5 \mathrm{~h})$.

\section{3-2. Everolimus Pharmacokinetic Study}

The results of the non-compartimental analysis in Fvb mice group and mdr1a-/1b- mice group after the administration of everolimus are summarized in Table 2.

As shown in Fig. 2, the oral administration of everolimus to the mdr1a-/1b- mice group resulted in a mean $\mathrm{C}_{\max } 1.3$ fold greater than the mean $\mathrm{C}_{\max }$ in the Fvb group. Also, $\mathrm{AUC}_{0 \rightarrow \text { Tlast }}$ of the mdr1a-/1b- group is 1.3 fold greater than $\mathrm{AUC}_{0 \rightarrow \text { Tlast }}$ of the Fvb group ( $p<0.001$, Bailer's method). The half-life of elimination were comparable (9.3 vs. $11.3 \mathrm{~h})$.

\section{3-3. Everolimus Pharmacokinetic After Lapatinib Pre-Treatment}

The results of the non-compartimental analysis after the administration of everolimus alone 
and after lapatinib pretreatment in Swiss mice are summarized in Table 3. As shown in Fig. 3, the oral administration of everolimus following a pre-treatment of lapatinib in Swiss mice resulted in a mean $\mathrm{C}_{\max } 1.7$ fold greater than the mean $\mathrm{C}_{\max }$ in everolimus alone group. In addition, the $\mathrm{AUC}_{0 \rightarrow \text { Tlast }}$ of the lapatinib pretreated Swiss mice group is 2.6 fold greater than $\mathrm{AUC}_{0 \rightarrow \text { Tlast }}$ of everolimus alone group $(p<0.001$, Bailer's method). The half-time of elimination were comparable (4.0 vs. $5.3 \mathrm{~h})$.

\section{3-4. Semiquantitative Determination of P-gp expression by Western Blot Analysis in intestine}

Western blot analysis of P-gp expression was performed on three parts of intestine (duodenum, jejunum, ileon) from three control mice and three mice pretreated with lapatinib ( $100 \mathrm{mg} / \mathrm{kg}$ of lapatinib twice a day for 2 days and $100 \mathrm{mg} / \mathrm{kg}$ of lapatinib on the third day). A $38.5 \%$ significant decrease was observed in duodenum segment in lapatinib pre-treated group as compared with control group $(0.298 \pm 0.08 v s .0 .183 \pm 0.05 ; p<0.05$, Wilcoxon test $)$ (see Fig. 4 and Fig. 5). Nevertheless, in jejunum and ileum segment, no significant difference of Pgp expression was observed $(0.58 \pm 0.43$ vs. $0.6 \pm 0.2$ and $0.47 \pm 0.11$ vs. $0.25 \pm 0.68$ respectively) (data not shown). 


\section{4- DISCUSSION}

The aim of this study was to document in vivo the effect of intestinal P-gp on everolimus disposition and to investigate the effect of lapatinib pre-treatment on everolimus pharmacokinetics and on intestinal P-gp expression.

In order to study the effect of P-gp on the disposition of everolimus, pharmacokinetics after oral administration of this drug was characterized in Fvb mice and mdr1a-/1-b mice. At the same time, the pharmacokinetics of digoxin, which is known to be a P-gp substrate [24], was realized.

The administration of the two molecules in mdrla-/1b- mice resulted in higher $\mathrm{C}_{\max }$ and $\mathrm{AUC}_{0 \rightarrow \text { Tlast }}$ as compared to those obtained in wild type mice. The application of Bailer's method has shown that the oral bioavaibility of both molecules was significantly higher in the mdrla-/1b- group than in the wild type group. In addition, half-lives of elimination in each group appear to be comparable. All these findings, added to the results obtained previously $[5,6]$, suggest that everolimus is transported by intestinal P-gp in mice like digoxin. However, the ratio of $\mathrm{AUC}_{0 \rightarrow \text { Tlast }}$ in everolimus group is lower than the ratio of $\mathrm{AUC}_{0 \rightarrow \text { Tlast }}$ in digoxin group. Unlike digoxin, everolimus is highly metabolized by cytochromes [7,8]. Thus, intestinal cytochromes could play a role in everolimus absorption and affect its $\mathrm{AUC}_{0 \rightarrow \text { Tlast }}$ after oral administration.

In order to document the influence of lapatinib on disposition of everolimus, pharmacokinetics study of this drug was carried in Swiss mice.

The first group of mice received everolimus alone $(0.25 \mathrm{mg} / \mathrm{kg})$. The second group of mice received everolimus after a lapatinib pre-treatment for two days $(100 \mathrm{mg} / \mathrm{kg}$, twice a day). A 2.6 fold increase of $\mathrm{AUC}_{0 \rightarrow \text { Tlast }}$ of everolimus was observed in mice pretreated by lapatinib as compared to everolimus alone. A 1.7 fold increase of everolimus $\mathrm{C}_{\max }$ was also observed. The 
elimination half-lifes were comparable (4.0 vs. $5.3 \mathrm{~h})$. In vitro and in vivo studies had shown that lapatinib is a substrate and an inhibitor of the P-gp as well as cytochromes $3 \mathrm{~A}$ and $2 \mathrm{C} 8$ $[18-20]$

Kovarick et al. have shown that when everolimus is coadmistrated with verapamil in 16 healthy subjects, 2.3 -fold increase of everolimus $\mathrm{C}_{\max }(21 \pm 8 \mathrm{vs} 47 \pm 18 \mathrm{ng} / \mathrm{ml})$ was observed and accompanied by 3.5 fold increase of $\mathrm{AUC}_{0 \rightarrow \text { Tlast }}(115 \pm 45 \mathrm{vs} 392 \pm 142 \mathrm{ng} / \mathrm{ml} . \mathrm{h})$. On the other hand, a slight prolongation of elimination half life has been noticed (32 \pm 6 vs. $37 \pm$ 6 h) [25]. When everolimus was coadministred with ketoconazole, a potent cytochrom 3A4 inhibitor, in 12 healthy volonteers, a 15 -fold $\mathrm{AUC}_{0 \rightarrow \text { Tlast }}$ increase has been observed, as compared to everolimus group alone. Also, a 1.9-fold prolongation of elimination half-life (30 \pm 4 vs $56 \pm 5 \mathrm{~h}$ ) was shown [12]. Verapamil is described like an important inhibitor of P-gp and less important inhibitor of cytochrom 3A while ketoconazole is both a potent inhibitor of P-gp and cytochrom 3A. In our results, an increase of 2.6-fold everolimus $\mathrm{AUC}_{0 \rightarrow \text { Tlast }}$ after a lapatinib pre-treatment was observed and accompanied with an slight prolongation of elimination half-life. Our results, when compared to those obtained in the previous study, suggest that lapatinib could have the same type of inhibition of P-gp and cytochromes as verapamil.

The determination of P-gp expression in intestines segments by Western Blot analysis showed that P-gp expression decreased only in duodenum in the lapatinib pretreated group as compared with the control group. No significant difference of P-gp expression was observed in jejunum and ileum. The concept of anatomical region-dependant modification of P-gp was already proposed to account for the inhibiting effect of some drugs on intestinal P-gp. For instance, IFN- $\alpha$ substantially inhibits P-glycoprotein expression in rats jejunum and ileum [26]. Quinidine increases ileal and jejunal digoxin absorption by inhibiting P-gp in rats [27]. An inhibition of duodenal P-gp expression by lapatinib could explain a decrease of the protein 
activity. Further investigations are needed to understand which regulators are implicated in the decrease of P-gp expression. However, it has been demonstrated that a HER-2 over expression leads to an induction of NF- $\mathrm{kB}$, a transcription factor controlling expression of genes which promote cell growth and survival [28]. In addition, it has been showed that NF$\kappa \mathrm{B}$ induces P-gp expression [29]. These findings lead us to think that one of the mechanisms of the decrease of the P-gp expression by the lapatinib could be due to an inhibition of HER-2 leading to a decrease of induction of NF- $\mathrm{KB}$ which could result in an inhibition of P-gp expression. Other mechanism of P-gp inhibition could be implicated. In vitro study showed that lapatinib could directly inhibit the function of P-gp by binding to their ATP-binding sites in order to stimulate the ATPase activity for its own transport [30]. However, the increase of everolimus $\mathrm{AUC}_{0 \rightarrow \text { Tlast }}$ after a lapatinib pre-treatment can not be explained by a competition of the two drugs transport by P-gp, as lapatinib last dose was administered 16 hours before the administration of everolimus. Thus, it is conceivable that lapatinib decreases P-gp expression, and so, enhances everolimus $\mathrm{AUC}_{0 \rightarrow \text { Tlast. }}$

It had been demonstrated that cyclosporine inhibits the first-pass extraction of everolimus by the intestine, rather than the liver in rats. Everolimus was administered 10 minutes after ciclosporin administration [31]. An inhibitory effect of lapatinib on the first-pass metabolism of everolimus by cytochromes P450 in the intestine could be lead to an increase of everolimus $\mathrm{AUC}_{0 \rightarrow \text { Tlast}}$, and $\mathrm{C}_{\max }$ without modifying the elimination half-life as noticed in our pharmacokinetic study. Nevertheless, as we discussed above, a combination of lapatinib and everolimus is necessary to evaluate a competition of the two drugs on proteins. If lapatinib was administered 16 hours before the administration of everolimus, a competition of the two drugs on cytochromes P450 couldn't be observed. However, an inhibition of cytochromes by lapatinib in mice liver could not be excluded. In order to confirm any inhibition of cytochromes, metabolite quantification should be done. Also, in vitro studies showed that 
lapatinib inhibits BCRP transporter [19]. However, no study has documented the influence of BCRP on everolimus disposition. Thus, the results obtained from our pharmacokinetic study and from the Western Blot analysis concerning everolimus and lapatinib interaction, suggest that lapatinib could enhance everolimus disposition by decreasing P-gp expression. Administration of everolimus in Fvb mice resulted in an increase of 4.1 fold of $\mathrm{AUC}_{0 \rightarrow \text { Tlast }}$ and 1.8 fold of $\mathrm{C}_{\max }$ higher than in Swiss mice. Obviously, absorption is enhanced, but also the elimination process appears to be different as half times of elimination are not comparable in the two strains. Many hypotheses could explain these results: physiological changes, differences in enzymatic arsenal, and protein expression according to the strains of mice.

In conclusion, this study showed first that everolimus is transported by P-gp in mice. In addition, a 2.6 fold significant increase of everolimus AUC was noticed after a lapatinib pretreatment.

These results show the necessity of a therapeutic monitoring of everolimus when it is administered with an inhibitor of P-gp and/or cytochromes like lapatinib in an anti-tumor treatment. Moreover, it could be relevant to document the pharmacological interaction of these two drugs in combination in order to observe an eventually competition on P-gp and cytochromes and therefore, an increase of a toxicity effect. Finally, everolimus and lapatinib are two drugs with anti-tumor properties, acting on two different pathogenesis way. Thus, lapatinib may increase the risk of toxicity associated with a higher concentration of everolimus in blood but equally the efficiency. Further investigations are necessary to document the pharmacodynamic effect of a pre-treatment of lapatinib on the anti-tumor activity of everolimus.

\section{5- ACKNOWLEDGEMENT}


We acknowledge Angélique Dauvin, Mirile Ganga, Aurélie Gasnier and Benoît Petit for the excellent technical assistance and Karine Ser-Leroux for the kind help in this project.

\section{6- REFERENCES}

[1] Ruiz JC, Sanchez A, Rengel M., Beneyto I, Plazza JJ. Use of the new proliferation signal inhibitor everolimus in renal transplant patients in Spain: preliminary results of the EVERODATA registry. Transplant Proc 2007;39(7):2157-9 Scopus.

[2] Rothenburger M, Teerling E, Bruch C, Lehmkuhl H, Suwelack B, Bara C et al. Calcineurin inhibitor-free immunosuppression using everolimus (Certican) in maintenance heart transplant recipients: 6 months' follow-up. J Heart Lung Transplant 2007;26(3):2507 Scopus.

[3] Gomez-Camarero J, Salcedo M, Rincon D, Lo Iacono O, Ripoll C, Hernando A et al. Use of Everolimus as a rescue immunosuppressive therapy in liver transplant patients with neoplasms. Transplantation 2007;84(6):786-91 Scopus.

[4] Mabuchi S, Altomare DA, Cheung M, Zhang L, Poulikakos PI, Hensley HH et al. RAD001 inhibits human ovarian cancer cell proliferation, enhances cisplatin-induced apoptosis, and prolongs survival in an ovarian cancer model. Clin Cancer Res 2007;13(14):4261-70 Scopus.

[5] Crowe A, Bruelisauer A, Duerr L, Guntz P, Lemaire M. Absorption and intestinal metabolism of SDZ-RAD and rapamycin in rats. Drug Metab Dispos 1999;27(5):627-32 Scopus.

[6] Laplante A, Demeule M, Murphy GF, Béliveau R. Interaction of immunosuppressive agents rapamycin and its analogue SDZ-RAD with endothelial PgP. Transplant Proc 2002; 34(8):3393-5 Scopus.

[7] Kovarik JM, Beyer D, Schmouder RL. Everolimus drug interactions: application of a classification system for clinical decision making. Biopharm Drug Dispos 2005;27(9):421-6 $\underline{\text { Scopus. }}$

[8] Kirchner GI, Meier-Wiedenbach I, Manns MP. Clinical pharmacokinetics of everolimus. Clin Pharmacokinet 2004;43(2):83-95 Scopus.

[9] Wacher VJ, Silverman JA, Zhang Y, Benet LZ. Role of P-glycoprotein and cytochrome P450 3A in limiting oral absorption of peptides and peptidomimetics. J Pharm Sci 1998;87(11):1322-30 Scopus.

[10] Fakhoury M, Litalien C, Medard Y, Cavé H, Ezzahir N, Peuchmaur M et al. Localization and mRNA expression of CYP3A and P-glycoprotein in human duodenum as a function of age. Drug Metab Dispos 2005;33(11):1603-7 Scopus.

[11] Saari TI, Laine K, Bertilsson L, Neuvonen PJ, Olkkola KT. Voriconazole and fluconazole increase the exposure to oral diazepam. Eur J Clin Pharmacol 2007;63(10):941-9 Scopus.

[12] Kovarik JM, Beyer D, Bizot MN, Jiang Q, Shenouda M, Schmouder RL. Blood concentrations of everolimus are markedly increased by ketoconazole. J Clin Pharmacol 2005;45(5):514-8 Scopus. 
[13] Schinkel AH, Mayer U, Wagenaar E, Mol CA, van Deemter L, Smit JJ et al. Normal viability and altered pharmacokinetics in mice lacking mdr1-type (drug - transporting) Pglycoprotein. Proc Natl Acad Sci U S A 1997;94(8):4028-33 Scopus.

[14] Piao YJ, Li X, Choi JS. Effects of verapamil on etoposide pharmacokinetics after intravenous and oral administration in rats. Eur J Drug Metab Pharmacokinet 2008;33(3):159-64 Scopus.

[15] Crowe A, Lemaire M. In vitro and in situ absorption of SDZ-RAD using a human intestinal cell line (Caco-2) and a single pass perfusion model in rats: comparison with rapamycin. Pharm Res 1998;15(11):1666-72 Scopus.

[16] Hegde PS, Rusnak D, Bertiaux M, Alligood K, Strum J, Gagnon R et al. Delineation of molecular mechanisms of sensitivity to lapatinib in breast cancer cell lines using global gene expression profiles. Mol Cancer Ther 2007;6(5):1629-40 Scopus.

[17] Geyer CE, Forster J, Lindquist D, Chan S, Romieu CG, Pienkowski T et al. Lapatinib plus capecitabine for HER2-positive advanced breast cancer. N Engl J Med 2006;355(26): 2733-43 Scopus.

[18] Collins D, O’Connor R, O’Donovan N, Clynes M, Crown J. Lapatinib inhibits Pglycoprotein (P-GP) and synergistically enhances taxane cytotoxicity in $\mathrm{PgP}+$ cell lines. Annals Onc 2006;17(S8):57

[19] Polli JW, Humphreys JE, Harmon KA, Castellino S, O'Mara MJ, Olson KL et al. The role of efflux and uptake transporters in N-\{3-chloro-4-[(3-fluorobenzyl)oxy]phenyl\}-6[5- (\{[2methylsulfonyl)ethyl]amino $\}$ methyl)-2-furyl]-4-quinazolinamine (GW572016, lapatinib) disposition and drug interactions. Drug Metab Dispos 2008;36(4):695-701 Scopus.

[20] Molina JR, Kaufmann SC, Reid J, Rubin S, Galvez-Peralta M, Friedman R et al. Evaluation of lapatinib and topotecan combination therapy: tissue culture, murine xenograft, and phase I clinical trial data. Clin Cancer Res 2008;14(23):7900-8.

[21] http://clinicaltrials.gov/

[22] Burtin P, Mentre F, van Bree J, Steimer JL. Sparse sampling for assessment of drug exposure in toxicological studies. Eur J Drug Metab Pharmacokinet 1996;21(2):105-11 Scopus.

[23] Bailer AJ. Testing for the equality of area under the curves when using destructive measurement techniques. J Pharmacokinet Biopharm 1998;16(3):303-9 Scopus.

[24] Bonhomme-Faivre L, Benyamina A, Reynaud M, Farinotti R, Abbara C. Disposition of Delta(9) tetrahydrocannabinol in CF1 mice deficient in mdr1a P-glycoprotein. Addic Biol 2008;13:295-300.

[25] Kovarik JM, Beyer D, Bizot MN, Jiang Q, Allison MJ, Schmouder RL. Pharmacokinetic interaction between verapamil and everolimus in healthy subjects. Br J Clin Pharmacol

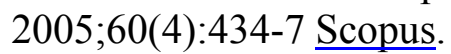

[26] Ben-Reguiga M, Bonhomme-Faivre L, Orbach-Arbouys S, Farinotti R. Modification of the P-glycoprotein dependent pharmacokinetics of digoxin in rats by human recombinant interferon- $\alpha$. Pharm Res 2005;22(11):1829-36 Scopus.

[27] Su SF, Huang JD. Inhibition of the intestinal digoxin absorption and exsorption by quinidine. Drug Metab Dispos 1996;24(2):142-7 Scopus.

[28] Pianetti S, Marcello A, Romieu-Mourez R, Coffey RJ, Sonenshein GE. Her-2/neu 
overexpression induces NF- $\mathrm{BB}$ via a PI3-kinase/ Akt pathway involving calpain-mediated degradation of I $\mathrm{B}-\alpha$ that can be inhibited by the tumor expressor PTEN. Oncogene 2001;20:1287-99 Scopus.

[29] Bentires-Alj M, Barbu V, Fillet M, Chariot A, Relic B, Jacobs N et al. NF-kappaB transcription factor induces drug resistance through MDR1 expression in cancer cells. Oncogene 2003;22(1):90-7.

[30] Dai CL, Tiwari AK, Wu CP, Su XD, Wang SR, Liu DG et al. Lapatinib (Tykerb, GW572016) reverses multidrug resistance in cancer cells by inhibiting the activity of ATP-binding cassette subfamily B member 1 and G member 2. Cancer Res 2008;68:790514.

[31] Yokomasu A, Yano I, Sato E, Masuda S, Katsura T, Inui K. Effect of intestinal and hepatic first-pass extraction on the pharmacokinetics of everolimus in rats. Drug Metab Pharmacokinet 2008;23(6):469-75. 
Table 1: Main pharmacokinetic parameters of digoxin after oral administration $(0.03 \mathrm{mg} / \mathrm{kg})$ obtained by a non-compartimental analysis in Fvb wild type and mdr1a-/1b- mice.

\begin{tabular}{|l|l|l|}
\hline & Fvb wild type & mdrla-/lb- \\
\hline Half - life $(\mathrm{hr})$ & 5.72 & 5.45 \\
\hline AUC $_{0_{\rightarrow} \text { Tlast }}(\mathrm{ng} . \mathrm{hr} / \mathrm{ml})$ & 42.13 & 250.58 \\
\hline Ratio AUC $_{0_{\rightarrow \text { Tlast }} \text { a }}$ & 5.9 & 4 \\
\hline $\mathrm{T}_{\max }(\mathrm{hr})$ & 0.25 & 18.8 \\
\hline $\mathrm{C}_{\max }(\mathrm{ng} / \mathrm{ml})$ & 6.3 & \\
\hline Ratio $\mathrm{C}_{\max }{ }^{\mathrm{b}}$ & 3.0 & \\
\hline
\end{tabular}

${ }^{\mathrm{a}}$ Ratio $\mathrm{AUC}_{0_{\rightarrow} \text { Tlast }}=\mathrm{AUC}_{0_{\rightarrow} \text { Tlast }}$ mdr1a-1/1b- group $/ \mathrm{AUC}_{0_{\rightarrow} \text { Tlast }}$ wild type group

${ }^{\mathrm{b}}$ Ratio $\mathrm{C}_{\max }=\mathrm{C}_{\max }$ mdr1a-1/1b-group / $\mathrm{C}_{\max }$ wild type group 
Table 2: Main pharmacokinetic parameters of everolimus after oral administration $(0.25$ $\mathrm{mg} / \mathrm{kg}$ ) obtained by a non-compartimental analysis in Fvb wild type and mdr1a-/1b- mice.

\begin{tabular}{|l|l|l|}
\hline & Fvb wild type & mdrla-/lb- \\
\hline Half -life (hr) & 9.3 & 11.3 \\
\hline AUC $_{0_{\rightarrow} \text { Tlast }}(\mathrm{ng} . \mathrm{hr} / \mathrm{ml})$ & 515.9 & 709.9 \\
\hline Ratio AUC ${ }_{0_{\rightarrow} \text { Tlast }}^{\text {a }}$ & 1.3 & 3 \\
\hline $\mathrm{T}_{\max }(\mathrm{hr})$ & 3 & 48.1 \\
\hline $\mathrm{C}_{\max }(\mathrm{ng} / \mathrm{ml})$ & 36.5 & \\
\hline Ratio $_{\max }^{\mathrm{b}}$ & 1.3 & \\
\hline
\end{tabular}

${ }^{\mathrm{a}}$ Ratio $\mathrm{AUC}_{0_{\rightarrow} \text { Tlast }}=\mathrm{AUC}_{0_{\rightarrow} \text { Tlast }}$ mdr1a-1/1b- group $/ \mathrm{AUC}_{0_{\rightarrow} \text { Tlast }}$ wild type group

${ }^{\mathrm{b}}$ Ratio $\mathrm{C}_{\max }=\mathrm{C}_{\max }$ mdr1a-1/1b-group / $\mathrm{C}_{\max }$ wild type group 
Table 3: Main pharmacokinetic parameters of everolimus $(0.25 \mathrm{mg} / \mathrm{kg})$ after oral administration $(0.25 \mathrm{mg} / \mathrm{kg})$ obtained by a non-compartimental analysis in Swiss mice.

\begin{tabular}{|l|l|l|}
\hline & everolimus & everolimus + lapatinib \\
\hline Half - life (hr) & 4.0 & 5.3 \\
\hline AUC $_{0_{\rightarrow} \text { Tlast }}(\mathrm{ng} . \mathrm{hr} / \mathrm{ml})$ & 128.3 & 332.6 \\
\hline Ratio AUC $_{0_{\rightarrow \text { Tlast }}{ }^{\mathrm{a}}}$ & 2.6 & 3 \\
\hline $\mathrm{T}_{\max }(\mathrm{hr})$ & 3 & 34.2 \\
\hline $\mathrm{C}_{\max }(\mathrm{ng} / \mathrm{ml})$ & 19.9 & \\
\hline Ratio $_{\max }^{\mathrm{b}}$ & 1.7 & \\
\hline
\end{tabular}

${ }^{\mathrm{a}}$ Ratio $\mathrm{AUC}_{0_{\rightarrow} \text { Tlast }}=\mathrm{AUC}_{0_{\rightarrow} \text { Tlast }}$ evero + lapa group $/ \mathrm{AUC}_{0_{\rightarrow \text { Tlast }}}$ evero group

${ }^{\mathrm{b}}$ Ratio $\mathrm{C}_{\max }=\mathrm{C}_{\max }$ evero+ lapa group / $\mathrm{C}_{\max }$ evero group 
Figure 1: Plot of time course of mean plasma digoxin concentrations (SD) after oral administration of digoxin at $0.03 \mathrm{mg} / \mathrm{kg}$ in Fvb and mdr1a-/1b- mice group $(n=3$ per group).

Figure 2: Plot of time course of mean plasma everolimus concentrations (SD) after oral administration of everolimus at $0.25 \mathrm{mg} / \mathrm{kg}$ in Fvb and mdrla- $/ 1 \mathrm{~b}$ - mice group $(n=3$ per group).

Figure 3: Plot of time course of mean plasma everolimus concentrations (SD) after oral administration of everolimus at $0.25 \mathrm{mg} / \mathrm{kg}$ alone and after oral pretreatment of lapatinib (100 $\mathrm{mg} / \mathrm{kg}$ twice a day) in Swiss mice ( $n=3$ per group).

Figure 4: Histogram of median P-gp / $\beta$ actin ratio \pm S.D. values from mouse duodenum $(n=$ 3 per group).

Figure 5: P-gp immunodetection from the duodenum of mice treated with 2 days of lapatinib (100 mg / kg twice a day) or control ( $n=3$ per group). 


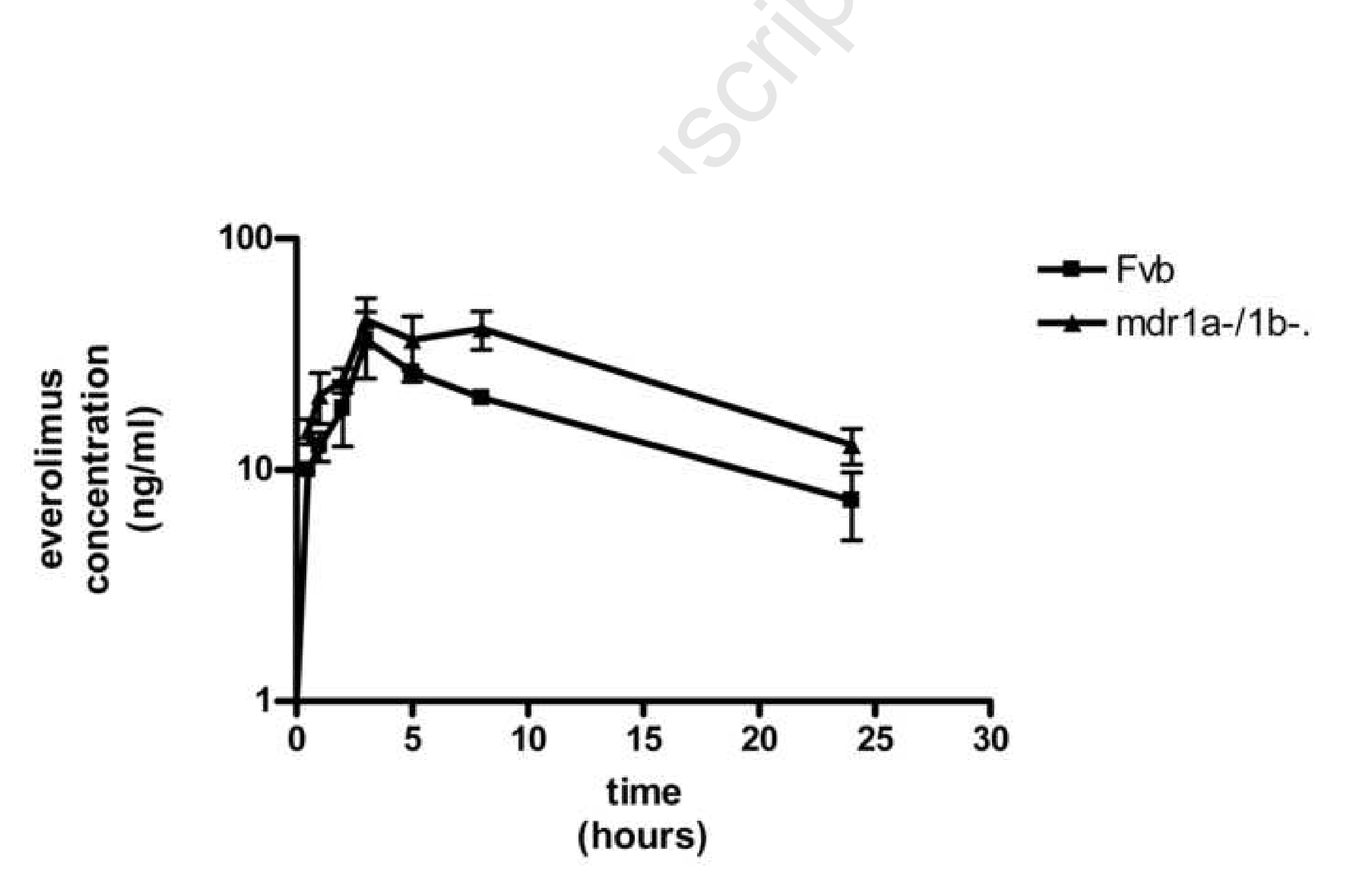

Figure 2

(hours)

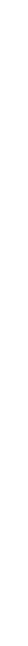

.

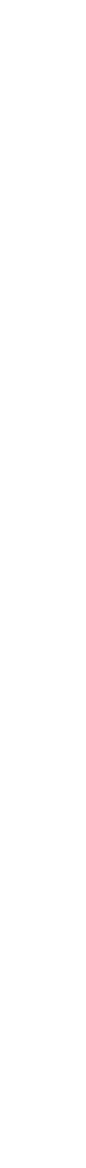




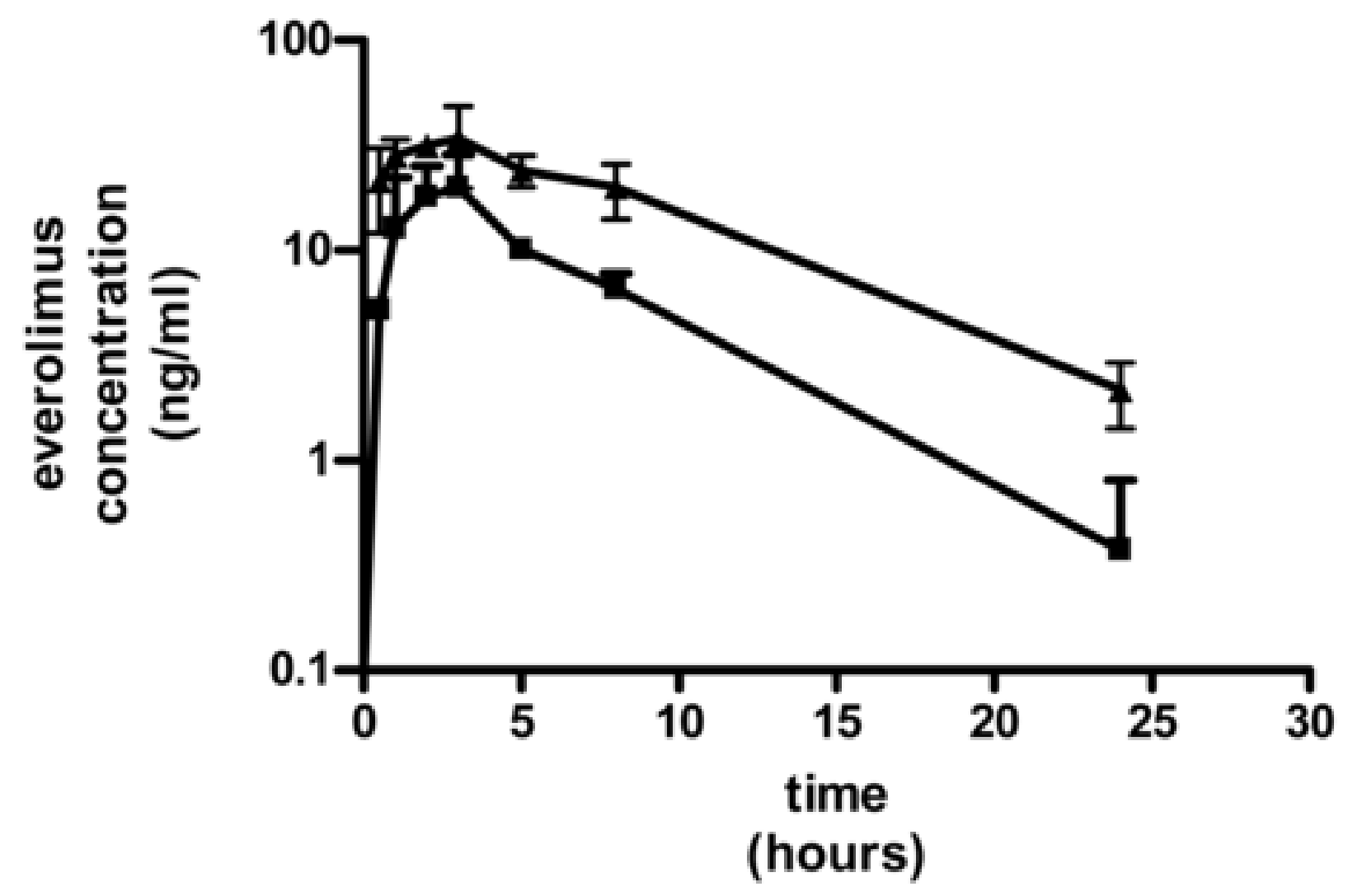

Figure 3 
Figure 4

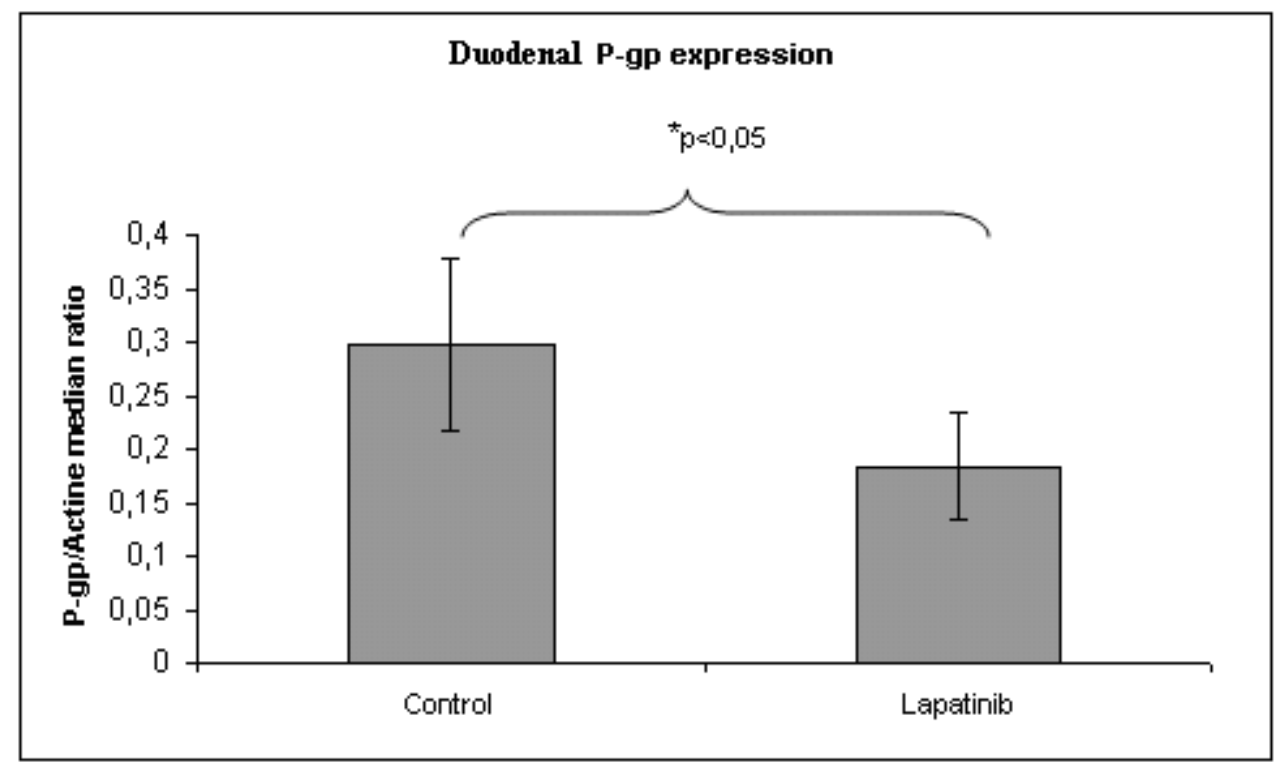


figure 5

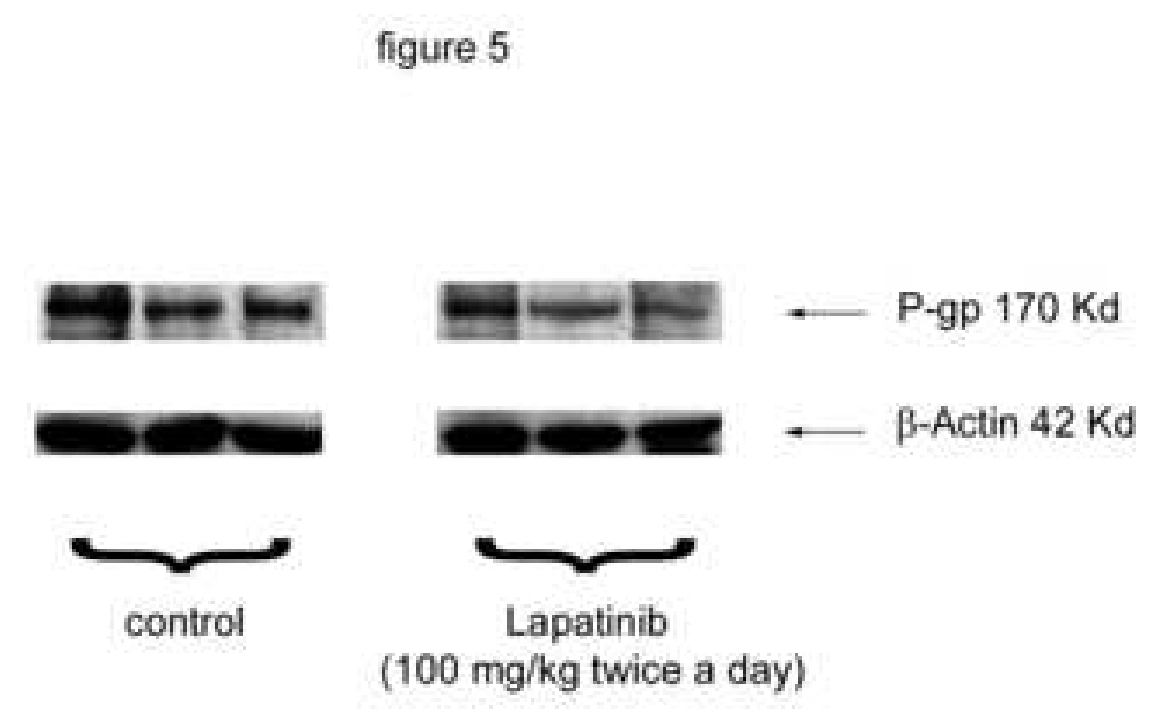

Page 28 of 28

(100 mg/kg twice a day)

inte

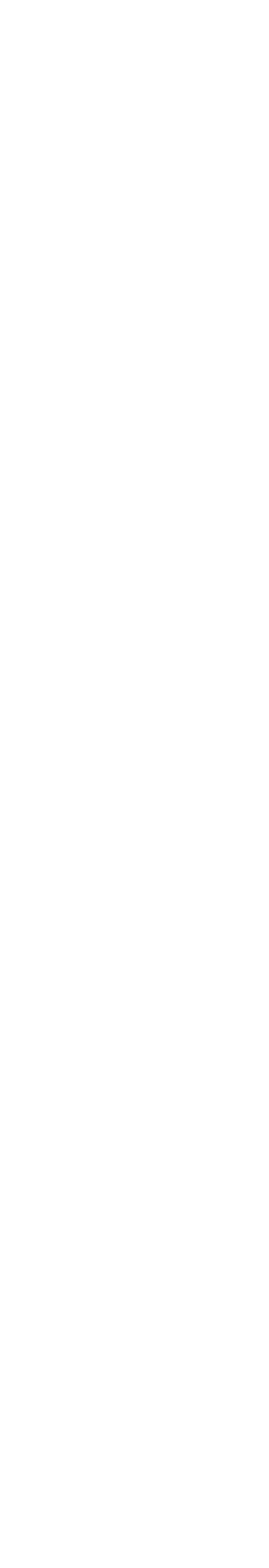

